\title{
PCR and DNA Hybridization Methods for Specific Detection of Bean-Infecting Begomoviruses in the Americas and Caribbean
}

\author{
J. L. Potter and M. K. Nakhla, University of Wisconsin-Madison, Madison; L. Mejía, Faculty of Agronomy, Uni- \\ versity of San Carlos, Guatemala; and D. P. Maxwell, University of Wisconsin-Madison, Madison 53706
}

\begin{abstract}
Potter, J. L., Nakhla, M. K., Mejía, L., and Maxwell, D. P. 2003. PCR and DNA hybridization methods for specific detection of bean-infecting begomoviruses in the Americas and Caribbean. Plant Dis. 87:1205-1212.

Begomoviruses are a major problem for common bean production in the tropics and subtropics of the Americas and the Caribbean. Multiplex polymerase chain reaction (PCR) primer pairs and nucleic acid hybridization probes have been developed to differentiate five bean-infecting begomoviruses and were used to assay reference and field-collected bean samples from Florida, Mexico, Central America, the Caribbean, and Brazil. Bean golden mosaic virus was found in Brazil, Bean calico mosaic virus in Mexico, and Bean golden yellow mosaic virus in Central America, the Caribbean, and Florida. Bean dwarf mosaic virus was not detected in any of the field samples. Tomato yellow leaf curl virus was found only in tomato samples from the Caribbean. These detection methods will provide tools to assist in the understanding of the epidemiology and diversity of geminiviruses as well as to facilitate resistance breeding, cultivar selection, and development of strategies for control.
\end{abstract}

Additional keywords: geminiviruses, Lycopersicon, nonradioactive hybridization, Phaseolus, Rhynchosia

Begomoviruses were initially described as minor pathogens on bean (Phaseolus vulgaris); however, after only a decade, fields approaching 100\% incidence were commonplace in parts of Latin America $(5,6,8,13,15,20)$. Five begomoviruses are found in field-grown beans: Bean golden mosaic virus (BGMV) $(8,17)$, Bean golden yellow mosaic virus (BGYMV) $(2,13,21)$, Bean calico mosaic virus (BCaMV) (6), Bean dwarf mosaic virus (BDMV) $(9,22,29)$, and most recently, Tomato yellow leaf curl virus (TYLCV) $(26,32,33)$. Begomoviruses possess circular, singlestranded DNA genomes and are transmitted by the whitefly Bemisia tabaci $(25,43)$.

Control of begomoviruses is complicated by several factors, such as reservoir hosts, rapid increases in whitefly populations, and continuous cropping of susceptible hosts. Weeds, which reside near or within crop fields, often display viral symptoms similar to those of crop plants; however, there is no report of weeds serving as a major source of inoculum for any begomovirus $(18,27,37)$. Besides elimination of sources of inoculum and reducing the vector populations, another option for

Corresponding author: Jamie L. Potter

E-mail: jlpotter76@yahoo.com

Accepted for publication 13 May 2003.

Publication no. D-2003-0721-02R

(C) 2003 The American Phytopathological Society control of viral diseases is the breeding of resistant cultivars. Breeding resistant bean cultivars has been difficult (1), and only moderately resistant cultivars are currently available $(28,30)$. Also, it is not known whether the genes for resistance to BGYMV (47) are effective against other bean-infecting begomoviruses. Since several bean-infecting begomoviruses cause similar symptoms, there can be confusion as to which begomovirus is present in a bean-breeding plot (e.g., BGYMV or BCaMV). Thus, rapid and accurate methods for specific viral identification will help expedite breeding programs.

Polymerase chain reaction (PCR) is a widely accepted method for the detection of geminiviruses $(4,33,40,44,49)$. Multiplex PCR was developed to detect multiple viral sequences in a single reaction $(7,12)$. Nucleic acid hybridization has been used to detect the presence of DNA or RNA of numerous plant viruses, e.g., RNA viruses $(24,34)$ and begomoviruses $(10,11,19,32$, 36,37,46,49). This report describes the development and use of PCR primer pairs and DNA probes for the specific detection of five bean-infecting begomoviruses.

\section{MATERIALS AND METHODS}

Standard sources of DNA for PCR and hybridization. The five beaninfecting begomoviruses were obtained from infected tissues and/or as full-length clones. BCaMV was from infected bean tissue provided by J. K. Brown, University of Arizona. BDMV, BGMV, and BGYMV were obtained as infectious clones and as bean tissue infected with progeny virus derived from these clones (19). TYLCV was generated from an infectious clone, pTYEG14 (data not shown). The viral DNA targets were obtained by extraction of infected tissue using the Dellaporta method, as described by Rojas et al. (40), or by preparation of plasmids of the fulllength infectious clones, BGMV, clone pBZA1 (18), BGYMV, clone PGAA1 (18), BDMV, clone pBDA1 (18), and TYLCV, clone pTYEG14. The mechanically transmissible viruses (BCaMV, BDMV, and BGYMV) were maintained by sap transmission in Phaseolus vulgaris cv. Top Crop (18). BGMV and TYLCV, which are not transmissible by sap inoculation, were maintained by particle bombardment of day-old radicals of bean seeds with fulllength DNA clones (18) using a helium particle delivery system. Leaf disks from infected leaves were prepared with a sterilized number 5 cork borer, placed in a sterilized $1.5-\mathrm{ml}$ microfuge tube, and stored at $-80^{\circ} \mathrm{C}$. Viral DNA extracted from infected tissue or PCR fragments prepared from the full-length clones using primer pair PRepv1978 and PCPc715, which are PAL1v1978 and PAL1c715 minus the $10 \mathrm{nt}$ on the $5^{\prime}$ end of the primer, respectively (40), served as positive controls for evaluation of the PCR and hybridization methods.

Field-collected samples for DNA extraction. B. tabaci samples were obtained from greenhouse-grown beans in Brazil and field-grown beans in Guatemala. The whiteflies were collected from plants exhibiting typical geminiviral symptoms and stored in $95 \%$ ethanol. Leaf tissue of beans, tomatoes, various weeds, and soybeans exhibiting begomoviral symptoms were collected from Florida, Brazil, Guatemala, Honduras, Mexico, Jamaica, and the Dominican Republic (Table 1). Tissues from young leaves were either dried or frozen after collection. Disks were cut from fresh leaf tissue with a flamesterilized number 5 cork borer, placed in sterilized $1.5-\mathrm{ml}$ microfuge tubes, and stored at $-80^{\circ} \mathrm{C}$. Also, for some samples, whole leaves were stored at $-80^{\circ} \mathrm{C}$ in plastic bags. Dry samples were stored either as whole leaves or as $0.5-\mathrm{mm}$ strips cut with a flame-sterilized blade, dried at room temperature, placed in paper envelopes, and stored at room temperature.

DNA from plant tissue was extracted by a modified Dellaporta method (40), by the 
Qiagen DNeasy plant extraction kit (Qiagen, Valencia, CA), or by a derivation of the Dellaporta method (designated the "heat extraction method"). Two leaf disks or 5 to $10 \mathrm{mg}$ of dried tissue were placed in 1.5 -ml microfuge tubes containing $500 \mu \mathrm{l}$ of the Dellaporta extraction buffer (40). Microfuge tubes with dry samples were placed on ice for 60 to 90 min to enhance the rehydration of the tissue. Tissues were macerated with a sterilized Kontes micropestle (Kontes Glass, Vineland, NJ). For the heat extraction method, ground tissue samples were boiled for $5 \mathrm{~min}$ at $95^{\circ} \mathrm{C}$, centrifuged for $10 \mathrm{~min}$ at $14,000 \mathrm{rpm}$ in an Eppendorf 5415C centrifuge (Brinkmann Instruments, Inc., Westbury, NY), and the supernatant collected in a separate 1.5-ml microfuge tube. Extraction of DNA from whiteflies was done by a modified

Table 1. Geographic origin and symptoms of field-collected tissue samples used in polymerase chain reaction (PCR) and DNA hybridization analyses

\begin{tabular}{|c|c|c|c|}
\hline Sample ID & Location & Symptoms & Collection date \\
\hline \multicolumn{4}{|l|}{ Phaseolus lunatus } \\
\hline $\mathrm{BR} 1$ & Goiânia, BR & Golden mosaic & Jun. 2000 \\
\hline \multicolumn{4}{|l|}{ Phaseolus vulgaris } \\
\hline DO5 & Azua Valley, DO & Golden mosaic & Feb. 2001 \\
\hline GT1, GT2, GT3, GT4 & Sanarate, GT & Golden mosaic & Nov. 2000, Apr. 2001 \\
\hline GT5, GT6, GT7 & Monjas, GT & Golden mosaic & Apr. 2001 \\
\hline GT8, GT9 & Palencia, GT & Golden mosaic & Nov. 2000 \\
\hline GT10, GT11 & Quetzaltenago, GT & Golden mosaic & Nov. 2000 \\
\hline GT12 & Jalapa, GT & Golden mosaic & Nov. 2000 \\
\hline FL1, FL2, FL3, FL4 & Homestead, FL & Golden mosaic & Jan. 2001 \\
\hline FL5, FL6 & Homestead, FL & Mottle & Jan. 2001 \\
\hline \multicolumn{4}{|l|}{ MX1, MX2, MX3, MX4 } \\
\hline MX5, MX6, MX7 & Los Mochis, MX & Golden mosaic & Apr. 2001 \\
\hline \multicolumn{4}{|l|}{ Phaseolus lathyroides } \\
\hline GT13 & Monjas, GT & Golden mosaic & Apr. 2001 \\
\hline \multicolumn{4}{|l|}{ Glycine $\max$} \\
\hline BR2 & Goiânia, BR & Golden mosaic & Jun. 2000 \\
\hline \multicolumn{4}{|l|}{ Rhynchosia minima } \\
\hline DO1 & Azua Valley, DO & Asymptomatic & Feb. 2001 \\
\hline $\mathrm{DO} 2$ & Azua Valley, DO & Golden mosaic & Feb. 2001 \\
\hline GT14, GT15 & Sanarate, GT & Golden mosaic & Apr. 2001 \\
\hline $\mathrm{HO} 1, \mathrm{HO} 2$ & Comayagua Valley, HO & Golden mosaic & Jul. 1999 \\
\hline JM1, JM2 & Bodles, JM & Golden mosaic & Jun. 2001 \\
\hline \multicolumn{4}{|l|}{ Euphorbia heterophylla } \\
\hline $\mathrm{BR} 4$ & Goiânia, BR & Golden mosaic & Jun. 2000 \\
\hline \multicolumn{4}{|l|}{ Croton lobatus } \\
\hline DO3 & Azua Valley, DO & Asymptomatic & Feb. 2001 \\
\hline DO4 & Azua Valley, DO & Golden mosaic & Feb. 2001 \\
\hline \multicolumn{4}{|c|}{ Malvastrum coromandelianum } \\
\hline GT16 & Sanarate, GT & Golden mosaic & Apr. 2001 \\
\hline \multicolumn{4}{|l|}{ Sida sp. } \\
\hline $\mathrm{HO}^{2}$ & Comayagua Valley, HO & Golden mosaic & Jul. 1999 \\
\hline BR3 & Goiânia, BR & Golden mosaic & Jun. 2000 \\
\hline \multicolumn{4}{|l|}{ Lycopersicon esculentum } \\
\hline JM3, JM4 & Bodles, JM & Leaf curl & Jun. 2001 \\
\hline
\end{tabular}

Table 2. Specific polymerase chain reaction (PCR) primer pairs designed to differentiate among the five bean-infecting begomoviruses

\begin{tabular}{lcclc}
\hline Primers $^{\mathbf{a}}$ & nt & Tm & Sequence $\left.\mathbf{( 5 '}^{\prime} \mathbf{3}^{\prime}\right)^{\mathbf{b}}$ & $\begin{array}{c}\text { Fragment } \\
\text { size }\end{array}$ \\
\hline PBCPRc23 & 26 & 79 & AAGGACCAAGCGAGAGAGAGGACACC & $350 \mathrm{bp}$ \\
PBCREPv2297 & 25 & 79 & CTGAATGTTCCTCTCGGGCGACTCG & \\
PTYLCPRc195 & 22 & 71 & GTGTAACCCTCGTGGGGACCAC & $846 \mathrm{bp}$ \\
PTYLCREPv2158 & 24 & 81 & CCATGGCCGCGCAGCGGAATACAC & \\
PBDPRc208 & 22 & 74 & GGCTGAGACGAAAGCAGTGCGC & $755 \mathrm{bp}$ \\
PBDREPv2090 & 24 & 72 & CCGGAGCCTTTTTGAATATGCTGG & \\
PBGYPRc122 & 26 & 72 & CGTGAGTGAATCTGATAATTCAMGAG & $650 \mathrm{bp}$ \\
PBGYMPv2049 & 25 & 76 & CTGCGACTGAATCTYGCAGATARTT & \\
PBGREPv2155 & 28 & 66 & GATATTGGAAGAGAAACTTTTCCGGTAG & $600 \mathrm{bp}$ \\
PBGCRc112 & 26 & 63 & CACGTGTCTACAGATCCTTAAAGAAC & \\
\hline
\end{tabular}

${ }^{\mathrm{a}} \mathrm{P}=$ primer, $\mathrm{BC}=$ Bean calico mosaic virus, $\mathrm{TYLC}=$ Tomato yellow leaf curl virus, $\mathrm{BD}=$ Bean $d$ warf mosaic virus, $\mathrm{BGY}=$ Bean golden yellow mosaic virus from $\mathrm{GT}, \mathrm{BG}=$ Bean golden mosaic virus, $\mathrm{PR}=$ promoter region, $\mathrm{REP}=$ Rep gene, $\mathrm{CR}=$ common region, $\mathrm{MP}=\mathrm{MP}$ gene, $\mathrm{v}=$ viral sense, $c=$ complementary sense, number $=$ GenBank sequence nucleotide number that corresponds to the $5^{\prime}$ nucleotide of the primer.

${ }^{\mathrm{b}}$ Degenerate primer codes: $\mathrm{D}=\mathrm{A}, \mathrm{G}, \mathrm{T} ; \mathrm{H}=\mathrm{A}, \mathrm{C}, \mathrm{T} ; \mathrm{M}=\mathrm{A}, \mathrm{C} ; \mathrm{N}=\mathrm{A}, \mathrm{C}, \mathrm{G}, \mathrm{T} ; \mathrm{R}=\mathrm{A}, \mathrm{G} ; \mathrm{W}=\mathrm{A}, \mathrm{T} ; \mathrm{Y}=$ $\mathrm{C}, \mathrm{T}$.

alkaline extraction method for leafhoppers (S. A. Miller, personal communication). Five to 10 whiteflies were used per extraction.

Primer design for PCR and PCR protocols. A specific PCR primer pair was developed for each of the five beaninfecting begomoviruses using regions of the viral genome identified by sequence alignments for the Rep (AC1) gene, common region, $C P(\mathrm{AV} 1)$ gene promoter, $M P$ (BC1) gene, and the hypervariable region of DNA-B (19,39). The Genetics Computer Group (GCG), Wisconsin Package Version 10.2 (Madison, WI) software was used for DNA manipulations. The viral genomes of interest were BGYMV isolates GT (M91604, M91605), MX (AF173555, AF173556), DO (L01635, L01636), PR (M10070, M10080), and FL (Homestead isolate, E. Hiebert, personal communication); TYLCV isolates EG (L12219), IS (X15656), and DO (AF02715); BGMV-BR (M88686, M88687); BDMV (M18879, M88180); and BCaMV (L22757, AF110190). Specific primer pairs, which could be used in multiplex PCR, were designed to anneal to regions conserved among isolates of a species but variable between species and to produce a fragment of a specific and unique length (Table 2).

The specificity and reproducibility of the specific primer pairs were tested by PCR with standard viral DNAs. PCR parameters were optimized for $25-\mu$ l reactions containing $0.25 \mathrm{mM}$ deoxynucleotide triphosphates (dNTPs), 1× Taq DNA polymerase buffer (Promega, Madison, WI), $0.25 \mathrm{mM}$ $\mathrm{MgCl}_{2}$ (Promega), 0.5 units Taq DNA polymerase (Promega), $2.5 \mu \mathrm{M}$ of each complementary and viral-sense primer, and $2.5 \mu \mathrm{l}$ of DNA extract (various concentrations). The target DNAs were serially diluted $(1: 10,1: 100,1: 1,000)$. PCR cycle parameters for fragment amplification were as follows: denaturation at $94^{\circ} \mathrm{C}$ for 1 min, annealing at $61^{\circ} \mathrm{C}$ for $2 \mathrm{~min}$, and extension at $72^{\circ} \mathrm{C}$ for $2 \mathrm{~min}$ for 30 cycles. These cycles were followed by a final cycle of $94^{\circ} \mathrm{C}$ for $1 \mathrm{~min}, 61^{\circ} \mathrm{C}$ for $2 \mathrm{~min}$, and $72^{\circ} \mathrm{C}$ for $7 \mathrm{~min}$, and then held at $18^{\circ} \mathrm{C}$. Amplified PCR fragments were separated by gel electrophoresis using 1.0 to $1.5 \%$ Seakem LE agarose (BioWhittaker Molecular Applications, Rockland, ME) for singleplex PCR and 3.0\% MetaPhor agarose for multiplex PCR reactions (BioWhittaker Molecular Applications).

Each sample was amplified with degenerate core $C P$ gene primer pair AV494 and AC1048 (49) with the same PCR conditions used for the specific PCR primer pairs, except that the annealing temperature was $55^{\circ} \mathrm{C}$. Samples that tested positive with the core $C P$ gene primer pair were then tested with the specific PCR primer pairs. PCR reactions were performed in a Perkin-Elmer Thermocycler (Perkin-Elmer Inc., Shelton, CT), a Techne Cyclogene Dry-Block Cycler (Techne Inc., Princeton, 
NJ), and/or a MJ DNA Engine PT200 Thermocycler (MJ Research Inc., Waltham, MA).

Nucleic acid hybridization probes and hybridization protocols. Nucleic acid hybridization techniques were developed with nonradioactive probes for dot blot detection of the five bean-infecting begomoviruses. Specific hybridization probes were designed using the common region of the viral genomes (Table 3). These regions differ among virus species but are highly conserved within a given species. A general probe for hybridization with begomoviruses was based on a region of the $C P$ gene highly conserved among begomoviruses found in the Americas and Caribbean (data not shown). PCR primer pairs PCPv647 (5' TATGTGTATATCCGATGTCACACGTGG $\left.3^{\prime}\right)$ and PCPc1048 (5' CGAATTTTCAATGTCGCATATACAGGG 3') were used to produce DNA for the general probe from DNA-A of clone pGAA1 of BGYMV isolate GT (18). Virus-specific DNA for probe labeling was produced by PCR with primer pairs listed in Table 3 using known viral DNAs as templates. PCR conditions for DNA probe amplification were the same as for the specific PCR primer pairs, except the annealing temperature was $55^{\circ} \mathrm{C}$.

In preliminary tests, two nonradioactive hybridization methods were compared by Potter (39) using the species-specific DNA probes. The Alk Phos Direct Hybridization Kit (Amersham Pharmacia, Piscataway, $\mathrm{NJ})$ gave stronger hybridization signals than the Roche Random Prime Hybridization Kit (Roche Molecular Biochemicals, Indianapolis, IN) and thus was used for this study. The PCR-amplified DNA probe was labeled according to the manufacturer's instructions (Amersham Pharmacia). Hybridization techniques for the specific probes used high stringency conditions with neutral-charged nylon membranes (Biodyne A, Pall-Gelman, Ann Arbor, $\mathrm{MI})$ at $65^{\circ} \mathrm{C}$ according to the manufacturer's (Amersham Pharmacia) instructions. Low stringency was used with the general $C P$ probe at $55^{\circ} \mathrm{C}$ according to manufacturer's instructions. Modifications to the hybridization protocols of the manufacturer are noted in Results.

Confirmation of specificity PCR primer pairs and DNA hybridization probes by sequence analysis of PCR fragments. To confirm the identification of the PCR-amplified fragments from the survey samples (Table 1), the PCR fragments from reactions with specific primer pairs and/or from reactions with the core $C P$ gene primer pair were directly sequenced at Biotechnology Center, Madison, WI, using the Big Dye Sequencing Kit (Applied Biosystems, Foster City, CA). Analysis of sample sequences was accomplished by comparison to known DNA sequences through the National Center Biotechnology Information BLAST pro-
Table 3. Polymerase chain reaction (PCR) primer pairs designed for amplification of specific DNA hybridization probes for the five bean-infecting begomoviruses

\begin{tabular}{lccll}
\hline Primer $^{\mathbf{a}}$ & nt & Tm & Sequence $\left(\mathbf{5}^{\prime} \mathbf{- 3}^{\mathbf{\prime}} \mathbf{}^{\mathbf{b}}\right.$ & $\begin{array}{c}\text { Fragment } \\
\text { length }\end{array}$ \\
\hline PGTCRc122 & 26 & 72 & CGTGAGTGAATCTGATAATTCAMGAG & $146 \mathrm{bp}$ \\
PGTCRv04 & 27 & 72 & CATATTTGTAAATAWGMGMGWGKMYHC & \\
PBZPRc252 & 25 & 72 & AACCCGTCAGCACAAAAGTTATTGG & $115 \mathrm{bp}$ \\
PBZREPv06 & 24 & 72 & AACGCTTTGGTGGTGGCATACTTG & \\
PTYCRc184 & 26 & 74 & CAACGAAATCCGTGAACAGATTCAGG & $350 \mathrm{bp}$ \\
PTYCRv2613 & 26 & 78 & CATGTTGAAATGAATCGGTGTCCCTC & \\
PBCCRc2556 & 23 & 74 & GCCCATGGTGTCCTAAAGAGGCC & $118 \mathrm{bp}$ \\
PBCCRv2464 & 21 & 62 & GTAAATATGAGCCAGGACACC & \\
PBDCRc109 & 24 & 72 & CACGTGTTCCGAAACCAGATTGAG & $129 \mathrm{bp}$ \\
PBDCRv07 & 23 & 70 & TTTTGTAATAAGAGCTGGTACTC & \\
\hline
\end{tabular}

a $\mathrm{P}=$ primer, $\mathrm{GT}=$ Bean golden yellow mosaic virus from $\mathrm{GT}, \mathrm{BC}=$ Bean calico mosaic virus, $\mathrm{TY}=$ Tomato yellow leaf curl virus, $\mathrm{BD}=$ Bean dwarf mosaic virus, $\mathrm{BZ}=$ Bean golden mosaic virus, $\mathrm{PR}=$ promoter region for coat protein, $\mathrm{REP}=\operatorname{Rep}$ gene, $\mathrm{CR}=$ common region, $\mathrm{c}=$ complementary sense, $\mathrm{v}=$ viral sense, number $=$ GenBank sequence nucleotide number that corresponds to the $5^{\prime}$ nucleotide of the primer.

${ }^{\mathrm{b}}$ Degenerate primer codes: $\mathrm{H}=\mathrm{A}, \mathrm{C}, \mathrm{T} ; \mathrm{M}=\mathrm{A}, \mathrm{C} ; \mathrm{W}=\mathrm{A}, \mathrm{T} ; \mathrm{Y}=\mathrm{C}, \mathrm{T}$.

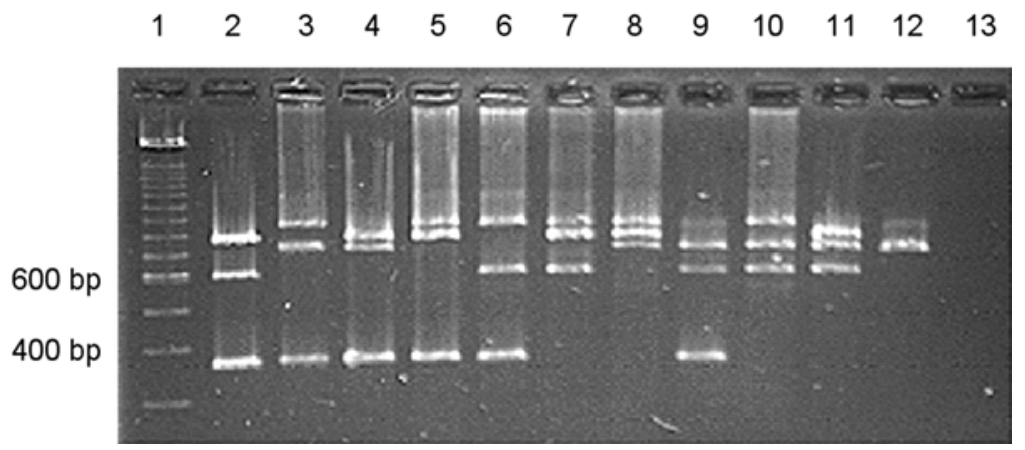

Fig. 1. Evaluation of designed primer pairs in a triplex polymerase chain reaction (PCR) on bean extracted DNA of bean-infecting begomoviruses. Each lane (2 to 12) contains primer pairs and DNA for viruses listed. Lane 1, 100-bp marker; lane 2, Bean calico mosaic virus (BCaMV), Bean dwarf mosaic virus (BDMV), Bean golden mosaic virus (BGMV); lane 3, BCaMV, Bean golden yellow mosaic virus (BGYMV), Tomato yellow leaf curl virus (TYLCV); lane 4, BCaMV, BDMV, BGYMV; lane 5, BCaMV, BDMV, TYLCV; lane 6, BCaMV, TYLCV, BGMV; lane 7, BDMV, TYLCV, BGMV; lane 8, BDMV, BGYMV, TYLCV; lane 9, BCaMV, BGYMV, BGMV; lane 10, BGYMV, TYLCV, BGMV; lane 11, BDMV, BGYMV, BGMV; lane 12, BGYMV for positive control; lane 13, asymtomatic bean extract for negative control with primer pair for BGYMV.

\section{TISSUES}

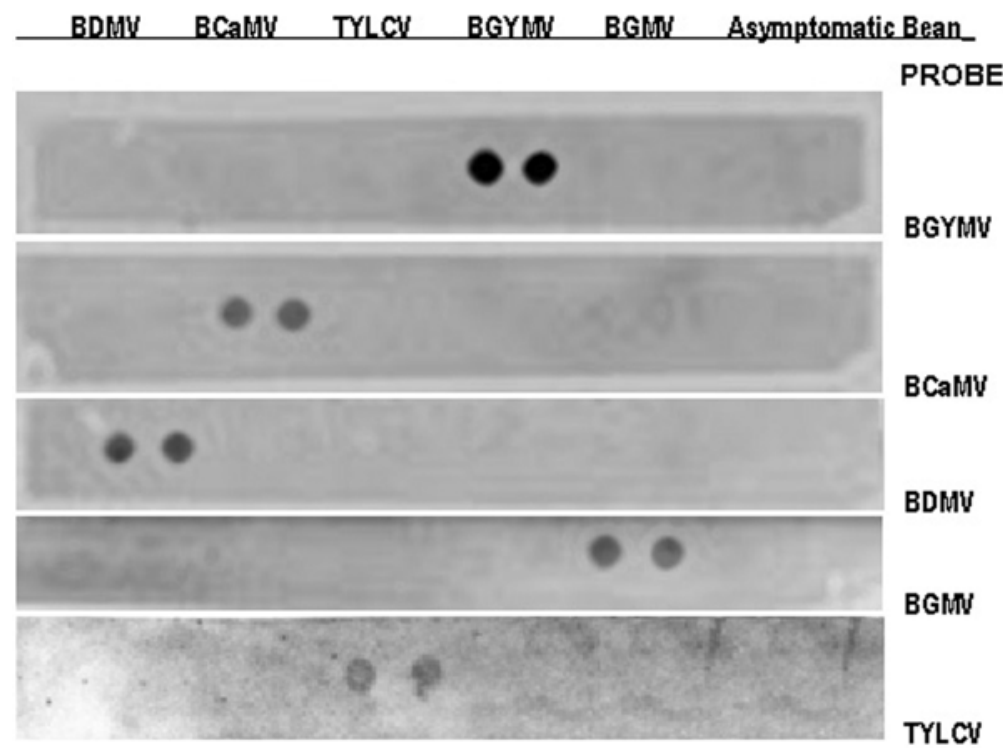

Fig. 2. Dot blot hybridization to evaluate the five specific DNA probes for detection of beaninfecting begomoviruses. Each membrane shows specificity of a probe to its respective viral DNA target, which was extracted from infected plant tissues. Text on the right indicates probes used on respective membranes. Text on top indicates plant tissue extract used at each location on all membranes. See Table 3 for information on specific probes. 
Table 4. Detection of bean-infecting begomoviruses in field-collected samples

\begin{tabular}{|c|c|c|c|c|c|c|}
\hline \multirow[b]{2}{*}{ Sample ID } & \multirow{2}{*}{$\begin{array}{c}\text { Storage } \\
\text { conditions }^{\text {a }}\end{array}$} & \multicolumn{2}{|c|}{ Hybridization } & \multicolumn{2}{|c|}{ PCR } & \multirow{2}{*}{$\begin{array}{c}\text { Method } \\
\text { for PCR }\end{array}$} \\
\hline & & General & Specific $^{b}$ & General & Specific $^{c}$ & \\
\hline \multicolumn{7}{|c|}{ Control tissues } \\
\hline \multicolumn{7}{|c|}{ P. vulgaris, asymptomatic } \\
\hline Bean & $\mathrm{F}$ & - & - & - & - & $\mathrm{H}$ \\
\hline BCaMV & $\mathrm{F}$ & 2.5 & $2.5 \mathrm{C}$ & + & $+\mathrm{C}$ & $\mathrm{H}$ \\
\hline BDMV & $\mathrm{F}$ & 3 & $3 \mathrm{D}$ & + & $+\mathrm{D}$ & $\mathrm{H}$ \\
\hline BGMV & $\mathrm{F}$ & 2 & 3 & + & $+Z$ & $\mathrm{H}$ \\
\hline BGYMV & $\mathrm{F}$ & 5 & $5 \mathrm{G}$ & + & $+\mathrm{G}$ & $\mathrm{H}$ \\
\hline TYLCV & $\mathrm{F}$ & - & $2 \mathrm{~T}$ & + & $+\mathrm{T}$ & $\mathrm{H}$ \\
\hline \multicolumn{7}{|c|}{ Field-collected tissues } \\
\hline \multicolumn{7}{|c|}{ P. vulgaris } \\
\hline $\mathrm{BR} 1$ & $\mathrm{D}$ & 1 & $3 Z$ & + & $+\mathrm{Z}$ & $\mathrm{H}$ \\
\hline DO5 & $\mathrm{D}$ & 4 & $4 \mathrm{G}$ & + & - & $\mathrm{H}$ \\
\hline FL1 & $\mathrm{F}$ & 2.5 & $2 \mathrm{G}$ & + & $+\mathrm{G}$ & $\mathrm{H}$ \\
\hline FL2 & $\mathrm{F}$ & 3.5 & $3 G$ & + & $+\mathrm{G}$ & $\mathrm{H}$ \\
\hline FL3 & $\mathrm{F}$ & 4 & $4 \mathrm{G}$ & - & - & $\mathrm{H}$ \\
\hline FL4 & $\mathrm{F}$ & 2 & $2 \mathrm{G}$ & + & $+\mathrm{G}$ & $\mathrm{H}$ \\
\hline FL5 & $\mathrm{F}$ & - & - & + & $+\mathrm{G}$ & D \\
\hline FL6 & $\mathrm{F}$ & - & - & + & $+\mathrm{G}$ & $\mathrm{H}$ \\
\hline GT1 & $\mathrm{F}$ & 4 & $3 G$ & + & $+\mathrm{G}$ & $\mathrm{H}$ \\
\hline GT2 & $\mathrm{F}$ & 5 & $5 \mathrm{G}$ & + & $+\mathrm{G}$ & $\mathrm{H}$ \\
\hline GT3 & $\mathrm{F}$ & 4 & $3 \mathrm{G}$ & + & $+\mathrm{G}$ & $\mathrm{H}$ \\
\hline GT4 & $\mathrm{F}$ & - & - & - & - & Q \\
\hline GT5 & $\mathrm{F}$ & 4.5 & $4 \mathrm{G}$ & + & $+\mathrm{G}$ & $\mathrm{H}$ \\
\hline GT6 & $\mathrm{F}$ & 3.5 & $3 G$ & + & $+\mathrm{G}$ & $\mathrm{H}$ \\
\hline GT7 & $\mathrm{F}$ & 4 & $4 \mathrm{G}$ & + & $+\mathrm{G}$ & $\mathrm{H}$ \\
\hline GT8 & D & - & - & - & - & $\mathrm{H}$ \\
\hline GT9 & D & - & $1 \mathrm{G}$ & - & - & $\mathrm{H}$ \\
\hline GT10 & D & 3 & $3 G$ & + & $+\mathrm{G}$ & D \\
\hline GT11 & D & 4 & $4 \mathrm{G}$ & - & - & $\mathrm{H}$ \\
\hline GT12 & D & - & - & - & - & $\mathrm{H}$ \\
\hline MX1 & D & 1 & $3 \mathrm{C}$ & + & $+\mathrm{C}$ & $\mathrm{H}$ \\
\hline MX2 & D & 3.5 & $5 \mathrm{C}$ & + & $+\mathrm{C}$ & $\mathrm{H}$ \\
\hline MX3 & D & 2 & $4 \mathrm{C}$ & + & $+\mathrm{C}$ & $\mathrm{H}$ \\
\hline MX4 & D & 2 & $4 C$ & + & $+\mathrm{C}$ & $\mathrm{H}$ \\
\hline MX5 & D & 2 & $4 \mathrm{C}$ & + & $+\mathrm{C}$ & $\mathrm{H}$ \\
\hline MX6 & D & 2 & $4 \mathrm{C}$ & + & $+\mathrm{C}$ & $\mathrm{H}$ \\
\hline MX7 & $\mathrm{D}$ & - & $2 \mathrm{C}$ & + & $+\mathrm{C}$ & $\mathrm{H}$ \\
\hline \multicolumn{7}{|c|}{$P$. lathyroides } \\
\hline GT13 & $\mathrm{F}$ & 1 & $1 \mathrm{G}$ & + & $+\mathrm{G}$ & $\mathrm{H}$ \\
\hline \multicolumn{7}{|l|}{ G. $\max$} \\
\hline BR2 & $\mathrm{D}$ & - & - & + & $+\mathrm{G}$ & Q \\
\hline \multicolumn{7}{|l|}{ R. minima } \\
\hline DO1 & $\mathrm{D}$ & - & - & - & - & Q \\
\hline DO2 & $\mathrm{D}$ & 1 & $4 Z$ & + & - & $\mathrm{H}$ \\
\hline GT14 & $\mathrm{F}$ & 3 & $3 Z$ & + & - & $\mathrm{H}$ \\
\hline GT15 & $\mathrm{F}$ & 1 & $3 Z$ & + & - & $\mathrm{D}$ \\
\hline $\mathrm{HO} 1$ & $\mathrm{D}$ & 4 & $5 Z$ & + & - & $\mathrm{D}$ \\
\hline $\mathrm{HO} 2$ & $\mathrm{D}$ & 3.5 & $2.5 \mathrm{Z}$ & + & - & $\mathrm{H}$ \\
\hline JM1 & $\mathrm{D}$ & 3 & - & + & - & Q \\
\hline $\mathrm{JM} 2$ & $\mathrm{D}$ & 2 & - & + & - & $\mathrm{Q}$ \\
\hline E. heteroph & & & & & & \\
\hline BR4 & $\mathrm{D}$ & 2 & - & + & - & Q \\
\hline C. lobatus & & & & & & \\
\hline DO3 & $\mathrm{D}$ & - & - & + & - & $\mathrm{D}$ \\
\hline DO4 & $\mathrm{D}$ & 3.5 & $4 Z$ & + & - & $\mathrm{H}$ \\
\hline M. coroman & & & & & & \\
\hline GT16 & $\mathrm{F}$ & 2 & $3 Z$ & + & - & $\mathrm{H}$ \\
\hline Sida sp. & & & & & & \\
\hline BR3 & $\mathrm{D}$ & 1 & - & + & - & $\mathrm{H}$ \\
\hline $\mathrm{HO} 3$ & $\mathrm{D}$ & 2 & - & + & - & $\mathrm{H}$ \\
\hline L. esculentu & & & & & & \\
\hline JM3 & $\mathrm{D}$ & 1 & $5 \mathrm{~T}$ & + & $+\mathrm{T}$ & $\mathrm{H}$ \\
\hline JM4 & $\mathrm{D}$ & 1 & $5 \mathrm{~T}$ & + & $+\mathrm{T}$ & $\mathrm{H}$ \\
\hline B. tabaci & & & & & & \\
\hline BRWF & $1 \mathrm{~F}$ & ND & ND & + & $+Z$ & $\mathrm{Z}$ \\
\hline GTWF & $2 \mathrm{~F}$ & ND & ND & + & $+\mathrm{G}$ & $\bar{Z}$ \\
\hline
\end{tabular}

a See Table 1 for information on samples. Letter = condition of tissue in storage; all tissue was collected fresh: $\mathrm{F}=$ frozen; $\mathrm{D}=$ dry.

b Hybridization intensity scale: $-=$ equal to asymptomatic bean (background); $1=+/-$, barely detectable against background; 2 = weak, but definite signal; $3=$ moderate signal; $4=$ strong signal; $5=$ very intense signal. General column $=$ hybridization with general $C P$ probe; specific column $=$ hybridization with five specific probes. For specific probe hybridizations, each resultant was given numerical designation followed by single-letter code for virus detected $(\mathrm{G}=$ Bean golden yellow mosaic virus, $\mathrm{Z}=$ Bean golden mosaic virus, $\mathrm{D}=$ Bean dwarf mosaic virus, $\mathrm{C}=$ Bean calico mosaic virus, and $\mathrm{T}=$ Tomato yellow leaf curl virus). ND = not done.

c Signals detected by polymerase chain reaction $(\mathrm{PCR})$ : + = visible band, $-=$ no visible band. General column $=$ PCR reaction using general core $C P$ gene primer pair; specific column $=$ PCR reaction using specific multiplex PCR primer pairs. For specific primer pair PCR reactions, each resultant was given $+/$ - designation followed by single-letter code for virus detected.

d Extraction method: $\mathrm{H}=$ heat extraction method; $\mathrm{Q}=$ Qiagen DNeasy plant extraction kit. gram and the GCG program. Sequences were considered to have come from the same virus when: fragments produced by specific primer pairs had $90 \%$ or greater identity for $200 \mathrm{nt}$ in the Rep gene or 100 nt in the common region; the hypervariable region of DNA-B had $85 \%$ or greater sequence identity for $200 \mathrm{nt}$ (19); or the core $C P$ gene fragments (49) had a $90 \%$ or greater identity for $200 \mathrm{nt}$ (43). Viral species identified in plant samples were then compared with results of the PCR and hybridization experiments with the specific primer pairs and specific probes to confirm the specificities of both techniques.

\section{RESULTS}

Evaluation of designed PCR primer pairs for detection of begomoviruses with cloned DNA and leaf extracts as target DNAs. Specific primer pairs designed for BGMV (PBGREPv2155 and PBGCRc112), BCaMV (PBCPRc23 and PBCREPv2297), BGYMV (PBGYPRc122 and PBGYMPv2049), TYLCV (PTYLCPRc195 and PTYLCREPv2158), and BDMV (PBDPRc208 and PBDREPv2090) produced the expected fragments of $600,350,650,850$, and 750 bp, respectively. In singleplex reactions, all primer pairs amplified only their respective viral DNA at an annealing temperature of $55^{\circ} \mathrm{C}$. In multiplex reactions, the specificity of the primer pair for each virus was obtained by using an annealing temperature of $61^{\circ} \mathrm{C}$ (Fig. 1).

Evaluation of designed hybridization probes for detection of geminiviral DNA with cloned DNA and leaf extracts. The PCR primer pairs (Table 3) designed to amplify specific DNA probes gave the expected sizes, which ranged from 120 to $350 \mathrm{bp}$. All probes were specific to their respective viral target and did not give hybridization signals from asymptomatic beans (Fig. 2). The specific probe for TYLCV more weakly hybridized to its respective target than the other specific probes, possibly due to the high AT content $(63 \%)$. The AT content of the other four probes was less than $60 \%$.

Field survey of plants collected in Central America, South America, the Caribbean, and Florida. The specificities of the PCR and hybridization techniques were assayed on field-collected tissues from Brazil, Honduras, Dominican Republic, Jamaica, Guatemala, and Florida (Table 1). PCR and hybridization tests for all samples were performed at the University of Wisconsin-Madison. Some samples at the University of San Carlos, Guatemala, were evaluated with both detection methods to determine the robustness of these techniques. Forty-three symptomatic samples and two asymptomatic plant samples were extracted by the heat extraction method and tested with PCR and hybridization methods. The general $C P$ gene 
probe gave hybridization signals with 36 of the 43 samples with symptoms and no signals with asymptomatic plants (Table 4). The core $C P$ gene primer pair detected begomoviruses in 38 of the 43 symptomatic plant samples and in none of the asymptomatic plant samples. Samples that did not show positive PCR signals with the heat extraction method were extracted by Dellaporta method (40) and/or by the Qiagen method (Table 4). The four samples with symptoms that did not give positive hybridization or PCR results were all stored as dried tissue.

The 39 samples that were positive for begomoviruses were further tested with the specific probes and specific PCR primer pairs for the five bean-infecting begomoviruses (Table 4). For the 21 bean samples, BGYMV was detected in the samples from Florida, Dominican Republic, and Guatemala (Fig. 3), BGMV in the sample from Brazil, and BCaMV in the samples from Mexico (Fig. 4). The P. lunatus from Brazil tested positive for BGMV. The G. $\max$ sample from Brazil did not give a hybridization signal with general or specific probes and only gave a PCR reaction with the core $C P$ gene primer pair. TYLCV was detected in the two tomato samples from Jamaica. For the 13 weed samples with begomoviruses, only the wild bean Phaseolus lathyroides (GT13) gave positive results for hybridization and PCR primers pairs, and this was for BGYMV. The other 13 weed samples gave negative results with the specific PCR primer pairs; however, seven of these samples gave positive hybridization signals with the BGMV probe.

The two whitefly samples gave positive results with the core $C P$ gene primer pair. With the specific PCR primer pairs, BGMV was detected in whiteflies from Brazil and BGYMV in those from Guatemala (Table 4). Hybridization probes were not tested on the whiteflies.

Confirmation of specificity of PCR primer pairs and hybridization probes by sequence analysis of PCR-amplified fragments. Twenty-three PCR-amplified fragments from the 43 plants tested were sequenced to confirm the specificity of the designed primer pairs and hybridization probes (Table 5). Of these fragments, 14 were from bean samples. The PCR products amplified with the BCaMV-specific primer pair from all five beans sequenced from Los Mochis, MX (MX1, MX2, MX4, MX6, MX7) had $90 \%$ or greater nucleotide identity to BCaMV (accession no. L22757, AF110189) for $200 \mathrm{nt}$ or more for the Rep gene or $100 \mathrm{nt}$ or greater for the common region. For the amplified PCR products with the BGYMV-specific primers, all five Guatemalan samples (GT1, GT4, GT5, GT6, GT10) had $85 \%$ or greater nucleotide identity to BGYMV (accession no. AF173556), the one sample from the Dominican Republic (DO5) had 92\% nucleo- tide sequence identity to BGYMV (accession no. L01636), all three samples from Florida (FL1, FL3, FL4) had $85 \%$ or greater nucleotide identity to BGYMV (accession no. AF173556) for $200 \mathrm{nt}$ for the hypervariable region of DNA-B (19). The PCR product amplified with the BGMV-specific primer pair from the $P$. lunatus sample from Brazil (BR1) had 92\% nucleotide identity to BGMV (accession no. M88688). PCR fragments obtained with the TYLCV-specific primer pair from the two tomato samples from Jamaica (JM3, JM4) had 93\% nucleotide identity to TYLCV (accession no. AF024715).

The PCR-amplified fragments from the six weeds were sequenced to identify the begomoviruses associated with these plants. The fragment obtained with the BGYMV-specific primer pair from the wild bean ( $P$. lathyroides, sample GT13) from Guatemala had $91 \%$ nucleotide identity to BGYMV (accession no. AF173556).

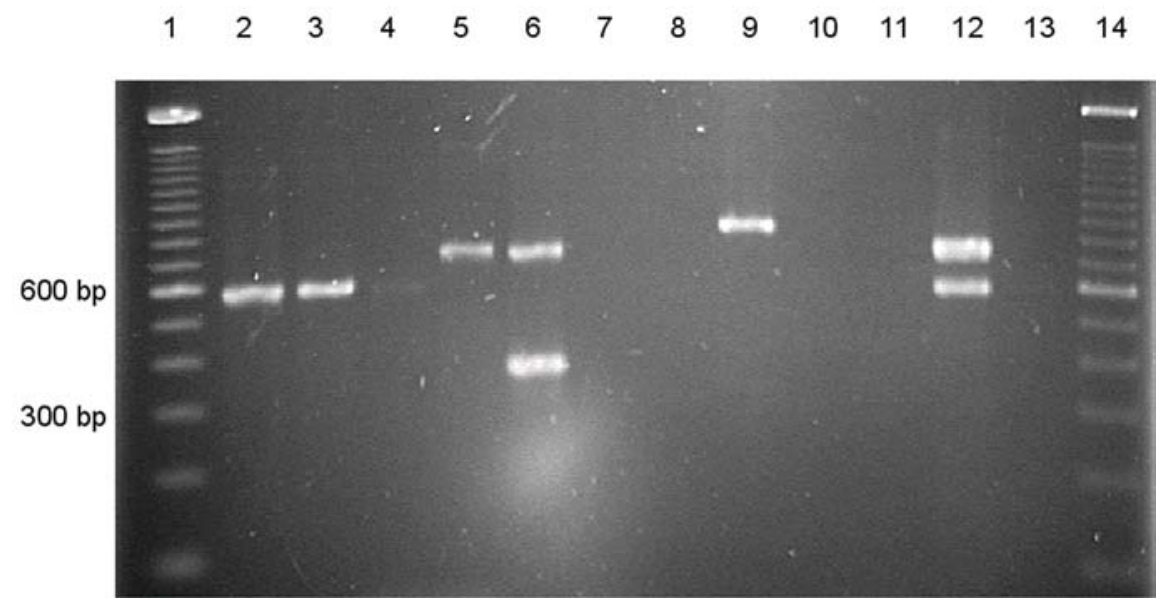

Fig. 3. Multiplex polymerase chain reaction (PCR) on field-collected symptomatic beans from Monjas, Guatemala. Agarose gel shows results of PCR amplification: lanes 1 and 14, 100-bp molecular marker; lanes 2, 3, and 4, core $C P$ gene primer pair with sample MF1-2, positive control (Bean golden yellow mosaic virus [BGYMV]), and negative control, respectively; lanes 5, 6, and 7, BGYMV and Bean calico mosaic virus (BCaMV) primer pairs with sample MF1-2, positive control (BGYMV and BCaMV), and negative control, respectively; lanes 8, 9, and 10, Tomato yellow leaf curl virus (TYLCV) primer pair with sample MF1-2, positive control (TYLCV), and negative control, respectively; lanes 11, 12, and 13, Bean golden mosaic virus (BGMV) and Bean dwarf mosaic virus (BDMV) primer pairs with sample MF1-2, positive control (BGMV and BDMV), and negative control, respectively. Sample information is listed in Table 1. Negative control is heat-extracted asymptomatic bean; positive controls are mixtures of heat-extracted infected bean of BGYMV, BCaMV, BGMV, BDMV, or TYLCV for respective primer pairs.

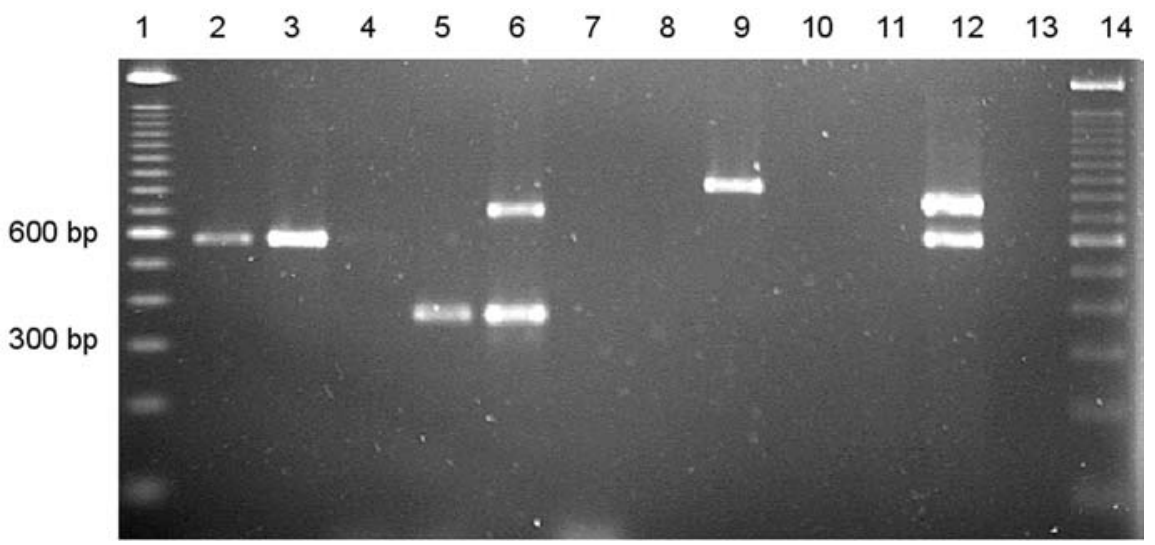

Fig. 4. Multiplex polymerase chain reaction (PCR) on field-collected symptomatic beans from Los Mochis, Mexico. Agarose gel for multiplex PCR amplification: lanes 1 and 14, 100-bp marker; lanes 2, 3, and 4, core $C P$ gene primer pair with sample MX1110, positive control (Bean golden yellow mosaic virus [BGYMV]), and negative control, respectively; lanes 5, 6, and 7, BGYMV and Bean calico mosaic virus (BCaMV) primer pairs with sample MX1110, positive control (BGYMV and $\mathrm{BCaMV}$ ), and negative control, respectively; lanes 8, 9, and 10, Tomato yellow leaf curl virus (TYLCV) primer pair with sample MX1110, positive control (TYLCV), and negative control, respectively; lanes 11, 12, and 13, Bean golden mosaic virus (BGMV) and Bean dwarf mosaic virus (BDMV) primer pairs with sample MX1110, positive control (BGMV and BDMV), and negative control, respectively. Sample information is listed in Table 1. Negative control is heat-extracted asymptomatic bean; positive controls are mixtures of heat-extracted infected bean of BGYMV, BCaMV, BGMV, BDMV, or TYLCV for the respective primer pairs. 
This sample tested positive for BGYMV BGYMV probe. For the remaining five weeds, PCR fragments were amplified by the core $C P$ gene primer pair. The PCRamplified fragment from the $R$. minima samples from Sanarate, GT, and Comayagua Valley, HO, (GT14, HO2) had 93 and 96\% nucleotide identity with Rhynchosia golden mosaic virus (accession no. AF408199 and AF239671, respectively). The PCR-amplified fragments from the $R$. minima from Jamaica and the Dominican Republic (JM1, DO2) had 94\% nucleotide identity with both Cabbage leaf curl virus (accession no. AF06815) and Pigeon pea yellow mosaic virus (PPYMV, accession no. AY628308), respectively. The PCRamplified fragment from $C$. lobatus from the Dominican Republic (DO4) had 88\% nucleotide identity with Cotton leaf crumple virus (accession no. AF076851).

\section{DISCUSSION}

Species-specific PCR primer pairs and DNA probes were developed for the detection of five bean-infecting begomoviruses, BGMV, BGYMV, BDMV, BCaMV, and TYLCV. These two techniques consistently with the specific primer pair and specific

and accurately detected and identified bean-infecting begomoviruses in bean samples from Brazil, the Dominican Republic, Guatemala, Mexico, and Florida. The species-specific PCR primer pairs were used effectively in multiplex PCR (Figs. 3 and 4). These species-specific detection methods were confirmed by sequence analysis (Table 5). In all cases, the sequence analysis of the PCR-amplified fragments indicated that the two methods had identified the correct virus in the sample. When no bean-infecting begomoviruses were detected by the multiplex PCR (e.g., samples DO2, DO4, GT14, HO2, JM1, JM2), the sequence analysis of the core $C P$ gene indicated that the samples were infected with a begomovirus other than one of the five bean-infecting begomoviruses. Similar results were obtained with the five specific DNA probes, except that the BGMV-specific probe gave weak hybridization signals with the extracts from $R$. minima collected in the Dominican Republic, Guatemala, and Honduras. Gilbertson et al. (18) also reported weak hybridization signals with a full-length DNA-B probe of BGMV with $R$. minima samples from the Dominican Republic. For

Table 5. Identification of begomoviruses associated with plant samples by analysis of sequence data of their polymerase chain reaction (PCR)-amplified fragments

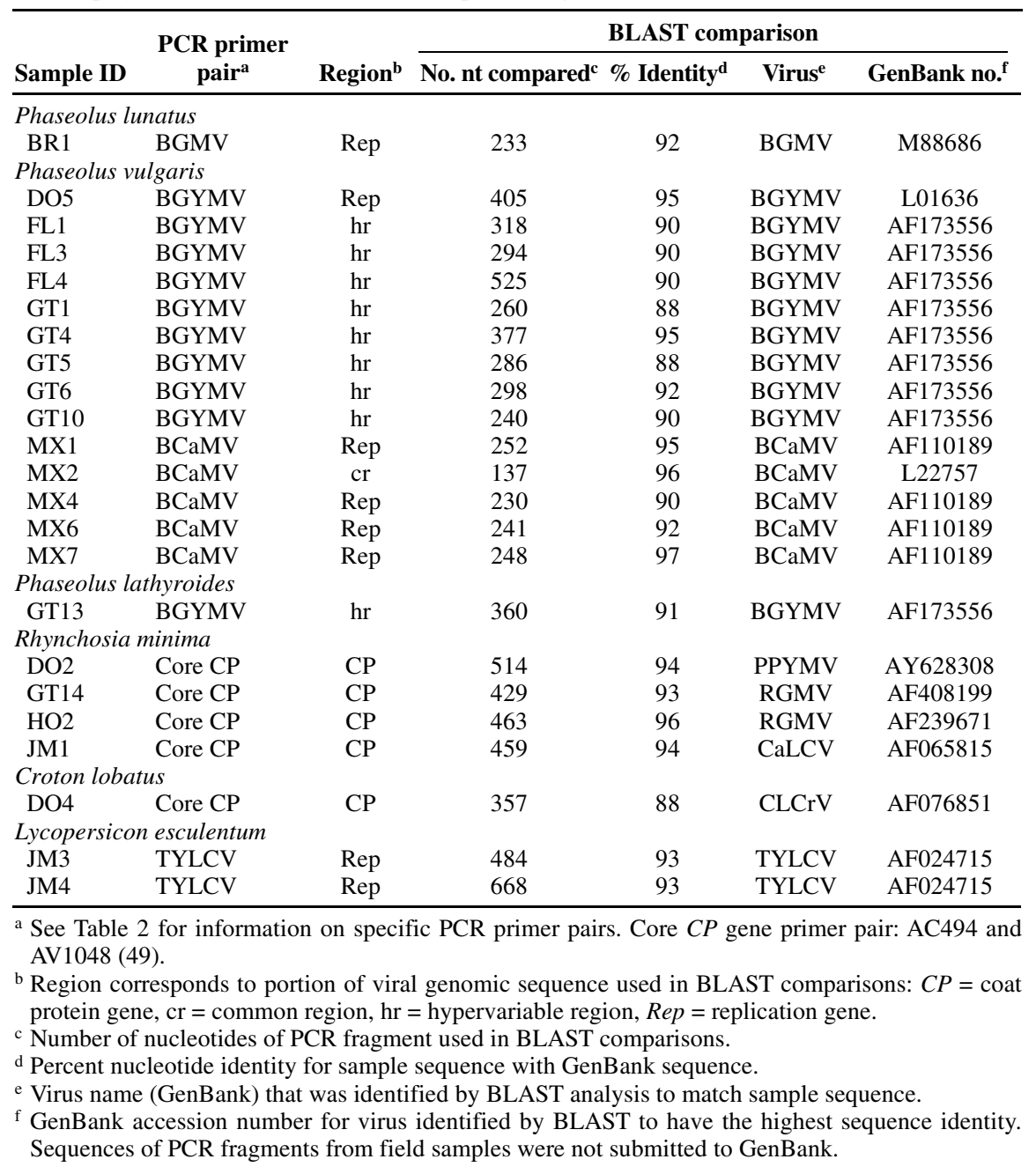

these $R$. minima samples, sequence analysis of the core $C P$ gene fragment indicated that the begomovirus associated with these samples was not BGMV. From these sequence confirmation results with bean, tomato, soybean, and weed samples, no false positives were obtained except as noted for the $R$. minima samples from the Dominican Republic, Guatemala, and Honduras. It will be necessary to sequence the begomoviruses associated with these $R$. minima samples to understand these hybridization results. Also, the bean-infecting begomoviruses identified are consistent with previous data on the distribution of these begomoviruses $(3,5,6,16,19,31,35$, 38-40,42,45,48). Moreover, the TYLCV primer pair effectively detected TYLCV in tomatoes with TYLCV symptoms collected in Jamaica and Florida (data not shown).

The multiplex PCR method was most effective with extracts prepared by the heat extraction method from frozen or fresh samples. Inconsistent results were obtained from the dry tissue samples with the heat extraction method or with plants that are high in phenolic compounds (e.g., R. minima) or polysaccharides (e.g., Sida sp.). The heat extraction method was reliable for extracts prepared from young leaves of tomatoes and beans, and thus could be used for the rapid processing of many plant samples. In those cases for which the heat extraction method gave inconsistent results for begomovirus detection, a more thorough extraction technique, such as the Dellaporta method (40) or the Qiagen DNeasy Plant DNA extraction method, was used. These alternative techniques were necessary for most weed samples.

Weeds have generally been considered an important source of inoculum for plant viruses. On the contrary, data from this study confirm those from previous studies, which showed that weeds, i.e., $R$. minima, C. lobatus, E. heterophylla, and M. coromandelium, are not an important host of bean-infecting begomoviruses $(14,18,23,41)$. However, BGYMV was associated with the wild bean weed, $P$. lathyroides, collected in Guatemala. This is new evidence for the possible role of reservoir hosts for BGYMV in Central America. The importance of this wild bean in the management of bean golden yellow mosaic disease should be studied.

The species-specific multiplex PCR techniques and nonradioactive hybridization method with species-specific DNA probes provide new tools for identification of the five bean-infecting begomoviruses. These methods are easier to use than the DNA hybridization methods with fulllength DNA-B probes for identification of the three bean-infecting begomoviruses reported by Gilbertson et al. (18). These two methods can be applied to multiple samples and thus have value in epidemiol- 
ogical studies and in plant breeding programs. Furthermore, the techniques can be readily adapted to other begomoviruses, such as those associated with tomatoes (35).

\section{ACKNOWLEDGMENTS}

J. L. Potter completed this research as part of the Master of Science Degree requirement. The authors express their appreciation to Martha D. Maxwell for review of the manuscript, and to R. McMillan, R. Gilbertson, R. Riley, M. M. Roca de Doyle, J. Faria, J. K. Brown, and M. Roye for collection of plant samples. This research was partially funded by the College of Agricultural and Life Sciences, University of Wisconsin-Madison, by a Hatch grant, and by a grant from the BeanCowpea CRSP/USAID program. J. L. Potter's research in Guatemala was partially supported by a Latin America, Caribbean, and Iberian Studies Program NAVE short-term research grant and a Graduate Women in Science Ruth Dickie Grant-inAid award.

\section{LITERATURE CITED}

1. Bianchini, A. 1999. Resistance to bean golden mosaic virus in bean genotypes. Plant Dis. 83:615-620.

2. Bird, J., Perez, J. E., Alconero, R., Vakili, N. G., and Melendez, P. L. 1972. A whiteflytransmitted golden yellow mosaic virus of Phaseolus vulgaris in Puerto Rico. Nucleic Acids Res. 16:4811-4829.

3. Blair, M. W., Bassett, M. J., Abouzid, A. M., Hiebert, E., Polston, J. E., McMillan, R. T., Jr., Graves, W., and Lamberts, M. 1995. Occurrence of bean golden mosaic-virus in Florida. Plant Dis. 79:529-533.

4. Briddon, R. W., and Markham, P. G. 1994. Universal primers for the PCR amplification of dicot-infecting geminiviruses. Mol. Biotechnol. 1:202-205.

5. Brown, J. K., and Bird, J. 1992. Whiteflytransmitted geminiviruses and associated disorders in the Americas and the Caribbean Basin. Plant Dis. 76:220-225.

6. Brown, J. K., Ostrow, K. M., Idris, A. M., and Stenger, D. C. 1999. Biotic, molecular, and phylogenetic characterization of bean calico mosaic virus, a distinct Begomovirus species with affiliation in the squash leaf curl virus cluster. Phytopathology 89:273-280.

7. Carvalho, R., Passos, L. M. F., and Martins, A. S. 2000. Development of a differential multiplex PCR assay for equine herpesvirus 1 and 4 as diagnostic tool. J. Vet. Med. 47:351359 .

8. Costa, A. S. 1965. Three whitefly-transmitted virus diseases of beans in São Paulo, Brazil. FAO Plant Prot. Bull. 13:1-12.

9. Costa, A. S. 1975. Increase in the populational density of Bemisia tabaci, a threat of widespread virus infection of legume crops in Brazil. Pages 27-49 in: Tropical Diseases of Legumes. J. Bird and K. Maramorosch, eds. Academic Press, New York.

10. Czosnek, H., Ber, R., Antignus, Y., Cohen, S., Navot, N., and Zamir, D. 1988. Isolation of tomato yellow leaf curl virus, a geminivirus. Phytopathology 78:508-512.

11. Czosnek, H., Ber, R., Navot, N., Zamir, D., Antignus, Y., and Cohen, S. 1988. Detection of tomato yellow leaf curl virus in lysates of plants and insects by hybridization with a viral DNA probe. Plant Dis. 72:949-951.

12. Elnifro, E. M., Ashshi, A. M., Cooper, R. J., and Klapper, P. E. 2000. Multiplex PCR: Optimization and application in diagnostic virology. Clin. Microbiol. Rev. 13:559-564.

13. Faria, J. C., Gilbertson, R. L., Hanson, S. F., Morales, F. J., Ahlquist, P., Loniello, A. O., and Maxwell, D. P. 1994. Bean golden mosaic geminivirus type II isolates from the Dominican Republic and Guatemala: Nucleotide sequence, infectious pseudorecombinants, and phylogenetic relationships. Phytopathology 84:321-329.

14. Frischmuth, T., Engel, M., Lauster, S., and Jeske, H. 1997. Nucleotide sequence evidence of the occurrence of three distinct whiteflytransmitted, Sida-infecting bipartite geminiviruses in Central America. J. Gen. Virol. 78:2675-2682.

15. Gálvez, G. E., and Morales, F. J. 1989. Whitefly-transmitted viruses. Pages 379-390 in: Bean Production Problems in the Tropics. $\mathrm{H}$. F. Schwartz and M. A. Pastor-Corrales, eds. CIAT, Cali, Columbia.

16. Garrido-Ramirez, E. R., Sudarshana, M. R., and Gilbertson, R. L. 2000. Bean golden yellow mosiac virus from Chiapas, Mexico: Characterization, pseudorecombination with other bean-infecting geminiviruses and germ plasm screening. Phytopathology 90:12241232.

17. Gilbertson, R. L., Faria, J. C., Ahlquist, P., and Maxwell, D. P. 1993. Genetic diversity in geminiviruses causing bean golden mosaic disease: The nucleotide sequence of the infectious cloned DNA components of a Brazilian isolate of bean golden mosaic geminivirus. Phytopathology 83:709-715.

18. Gilbertson, R. L., Hidayat, S. H., Martinez, R. T., Leong, S. A., Faria, J. C., Morales, F. J., and Maxwell, D. P. 1991. Differentiation of bean-infecting geminiviruses by nucleic acid hybridization probes and aspects of bean golden mosaic in Brazil. Plant Dis. 75:336342.

19. Gilbertson, R. L., Rojas, M. R., Russell, D. R., and Maxwell, D. P. 1991. Use of the asymmetric polymerase chain reaction and DNA sequencing to determine genetic variability of bean golden mosaic geminivirus in the Dominican Republic. J. Gen. Virol. 72:2843-2848.

20. Goodman, R. M. 1977. Single-stranded DNA genome in a whitefly-transmitted plant virus. Virology 83:171-179.

21. Goodman, R. M., Bird, J., and Thongmeearkom, P. 1977. An unusual virus like particle associated with golden yellow mosaic of beans. Phytopathology 67:37-42.

22. Hidayat, S. H., Gilbertson, R. L., Hanson, S. F., Morales, F. J., Ahlquist, P., Russell, D. R., and Maxwell, D. P. 1993. Complete nucleotide sequences of the infectious cloned DNAs of bean dwarf mosaic geminivirus. Phytopathology 83:181-187.

23. Hofer, P., Engel, M., Jeske, H., and Frischmuth, J. 1997. Nucleotide sequence of a new bipartite geminivirus isolated from the common weed, Sida rhombifolia, in Costa Rica. J. Gen. Virol. 78:1785-1790.

24. Lobenstein, G., Akad, F., Filatov, V., Sadvakasova, G., Manadilova, A., Bakelman, H., Teverovsky, E., Lachmann, O., and David, A. 1997. Improved detection of potato leafroll luteoviruses in leaves and tubers with a digoxigenin-labeled cRNA probes. Plant Dis. 81:489-491.

25. Markham, P. G., Bedford, I. D., Liu, S., Frolich, D. F., Rosell, R., and Brown, J. K. 1996. The transmission of geminiviruses by biotypes of Bemisia tabaci (Gennadius). Pages 69-76 in: Bemisia: 1995 Taxonomy, Biology, Damage, Control and Management. D. Gerling and R. T. Mayer, eds. Intercept Ltd., Andover, UK.

26. Martínez Zubiaur, Y., Quiñones, M., Fonseca, D., Potter, J. L., and Maxwell, D. P. 2002. First report of Tomato yellow leaf curl virus associated with beans, Phaseolus vulgaris, in Cuba. Plant Dis. 86:814

27. McGovern, R. J., Polston, J. E., Danyluk, G.
M., Hiebert, E., Abouzid, A. M., and Stanley, P. A. 1994. Identification of a natural weed host of tomato mottle geminivirus in Florida. Plant Dis. 78:1102-1106.

28. McMillan, R. T., Davis, M. R., McLaughlin, H. J., and Stavely, J. R. 1998. PCR evaluation of fourteen bean golden mosaic virus (BGMV) resistant snap bean germplasm lines for the presence of the virus. Annu. Rep. Bean Improv. Coop. 41:31-32.

29. Morales, F., Niessen, A., Ramirez, B., and Castaño, M. 1990. Isolation and partial characterization of a geminivirus causing bean dwarf mosaic. Phytopathology 80:96-101.

30. Morales, F. J., and Singh, S. P. 1993. Breeding for resistance to bean golden mosaic virus in an interracial population of Phaseolus vulgaris L. Euphytica 67:59-63.

31. Nakhla, M. K., Maxwell, D. P., Carvalho, M. G., and Gilbertson, R. L. 1994. Widespread occurrence of the eastern Mediterranean strain of tomato yellow leaf curl geminivirus in tomatoes in the Dominican Republic. Plant Dis. 78:926.

32. Navas-Castillo, J., Sánchez-Campos, S., Diaz, J. A., Saez-Alonso, E., and Moriones, E. 1999. Tomato yellow leaf curl virus-Is causes a novel disease of common bean and severe epidemics in tomato in Spain. Plant Dis. 83:29-32.

33. Navot, N., Zeidan, M., Pichersky, E., Zamir, D., and Czosnek, H. 1992. Use of the polymerase chain reaction to amplify tomato yellow leaf curl virus DNA from infected plants and viruliferous whiteflies. Phytopathology 82:1199-1202.

34. Perez, E. E., Weingartner, D. P., Hiebert, E., and McSorlet, R. 2000. Tobacco rattle virus detection in potato tubers from northeast Florida by PCR and tissue blotting. Am. J. Potato Res. 77:363-368.

35. Polston, J. E., and Anderson, P. K. 1997. The emergence of whitefly-transmitted geminiviruses in tomato in the Western Hemisphere. Plant Dis. 81:1358-1369.

36. Polston, J. E., Dodds, J. A., and Perring, T. M. 1989. Nucleic acid probes for detection and strain discrimination of cucurbit geminiviruses Phytopathology 79:1123-1127.

37. Polston, J. E., Hiebert, E., McGovern, R. J. Stansly, P. A., and Schuster, D. J. 1993. Host range of tomato mottle virus, a new geminivirus infecting tomato in Florida. Plant Dis. 77:11811184.

38. Polston, J. E., McGovern, R. J., and Brown, L. G. 1999. Introduction of tomato yellow leaf curl virus in Florida and implications for the spread of this and other geminiviruses of tomato. Plant Dis. 83:984-988.

39. Potter, J. L. 2002. PCR and DNA hybridization methods for specific detection and identification of bean-infecting geminiviruses. M.Sc. thesis. University of Wisconsin-Madison, Madison.

40. Rojas, M. R., Gilbertson, R. L., Russell, D R., and Maxwell, D. P. 1993. Use of degenerate primers in the polymerase chain reaction to detect whitefly-transmitted geminiviruses. Plant Dis. 77:340-347.

41. Roye, M. E., McLaughlin, W. A., Nakhla, M. K., and Maxwell, D. P. 1997. Genetic diversity among geminiviruses associated with the weed species Sida spp., Macroptilium lathyroides, and Wissadula amplissima from Jamaica. Plant Dis. 81:1251-1258.

42. Roye, M. E., Wernecke, M. E., McLaughlin, W. A., Nakhla, M. K., and Maxwell, D. P. 1999. Tomato dwarf leaf curl virus, a new bipartite geminivirus associated with tomatoes and peppers in Jamaica and mixed infection with tomato yellow leaf curl virus. Plant Pathol. 48:370-378.

43. Rybicki, E. P., Briddon, R. W., Brown, J. K., 
Fauquet, C. M., Maxwell, D. P., Harrison, B. D., Markham, P. G., Bisaro, D. M., Robinson, D., and Stanley, J. 2000. Family Geminiviridae. Pages 285-297 in: Virus Taxonomy: Classification and Nomenclature of Viruses. M. H. V. van Regenmortel, C. M. Fauquet, D. H. L. Bishop, E. B. Carstens, M. K. Estes, S. M. Lemon, J. Maniloff, M. A. Mayo, D. J. McGeoch, C. R. Pringle, and R. B. Wickner, eds. Academic Press, San Diego, CA.

44. Rybicki, E. P., and Hughes, F. L. 1990. Detection and typing of maize streak virus and other distantly related geminiviruses of grasses by polymerase chain reaction amplifi- cation of a conserved viral sequence. J. Gen. Virol. 71:2519-2526.

45. Salati, R., Nakhla, M. K., Rojas, M. R., Guzman, P., Jaquez, J., Maxwell, D. P., and Gilbertson, R. L. 2002. Tomato yellow leaf curl virus in the Dominican Republic: Characterization of an infectious clone, virus monitoring in whiteflies, and identification of reservoir hosts. Phytopathology 92:487-496.

46. Sánchez-Campos, S., Navas-Castillo, J., Camero, R., Soria, C., Diaz, J. A., and Moriones, E. 1999. Displacement of tomato yellow leaf curl virus (TYLCV)-Sr by TYLCV-Is in tomato epidemics in Spain. Phytopathology 89:1038-1043.
47. Singh, S. P., Morales, F. J., Miklas, P. N., and Teran, H. 2000. Selection for bean golden mosaic resistance in intra- and interracial bean populations. Crop Sci. 40:1565-1572.

48. Torres-Pacheco, I., Garzon-Tiznado, J. A., Brown, J. K., Becerra-Flora, A., and RiveraBustamante, R. F. 1996. Detection and distribution of geminiviruses in Mexico and the southern United States. Phytopathology 86:1186-1192.

49. Wyatt, S. D., and Brown, J. K. 1996. Detection of subgroup III geminivirus isolates in leaf extracts by degenerate primers and polymerase chain reaction. Phytopathology 86:1288-1293. 